\title{
Soft tissue metastases from differentiated thyroid cancer diagnosed by ${ }^{18}$ F FDG PET-CT
}

\author{
Metástases em tecidos moles de câncer de \\ tireoide diagnosticadas por ${ }^{18}$ F FDG PET-CT
}

Inés Califano', Sergio Quildrian², Martín Coduti3 Erica Rojas Bilbao ${ }^{4}$, José Otero², Leonardo Califano ${ }^{3}$

\section{SUMMARY}

Distant metastases of differentiated thyroid cancer are unusual; lung and bones are the most frequently affected sites. Soft tissue metastases (STM) are extremely rare. We describe two cases of patients with differentiated thyroid cancer metastasizing to soft tissues. Both patients had widespread metastatic disease; clinically asymptomatic soft tissue metastases were found by ${ }^{18}$-Fluordeoxyglucose positron emission tomography/computed tomography ( ${ }^{18} \mathrm{~F} \mathrm{FDG} \mathrm{PET-CT),}$ and confirmed by cytological and/or histopathological studies. These findings underscore the ability of ${ }^{18} \mathrm{~F}$ FDG PET-CT in accurately assessing the extent of the disease, as well as the utility of the method to evaluate regions of the body that are not routinely explored. Arq Bras Endocrinol Metab. 2013;57(4):317-21

\section{SUMÁRIO}

As metástases a distância em carcinoma diferenciado de tireoide são raras. Pulmão e ossos são os lugares mais frequentemente atingidos. As metástases em tecidos moles são extremamente infrequentes. Neste artigo, descrevemos dois casos de pacientes com câncer diferenciado de tireoide com metástases em tecidos moles. Ambos os pacientes padeciam de enfermidade avançada. As metástases em partes moles foram assintomáticas e detectadas mediante ${ }^{18}$-Fluordeoxyglucose positron emission tomography/computed tomography ( ${ }^{18} \mathrm{~F}$ FDG PET-CT), sendo confirmadas por citologia e/ou histopatologia. Esses achados ressaltam o valor do ${ }^{18} \mathrm{~F}$ FDG PET-CT para a avaliação correta da extensão da enfermidade e a utilidade do método para avaliar regiões do corpo que não são exploradas nos estudos de rotina. Arq Bras Endocrinol Metab. 2013;57(4):317-21

\author{
1 Service of Endocrinology, \\ Instituto de Oncología "Angel \\ H. Roffo", Universidad de \\ Buenos Aires, Argentina \\ 2 Department of Soft Tissues \\ Surgery, Instituto de Oncología \\ "Angel H. Roffo", Universidad \\ de Buenos Aires, Argentina \\ ${ }^{3}$ Department of Head and Neck \\ Surgery, Instituto de Oncología \\ "Angel H. Roffo," Universidad \\ de Buenos Aires, Argentina \\ ${ }^{4}$ Department of Pathology, \\ Instituto de Oncología "Angel \\ H. Roffo", Universidad de \\ Buenos Aires, Argentina \\ Correspondence to: \\ Inés Califano \\ Service of Endocrinology, \\ Instituto de Oncología "Angel H. \\ Roffo", \\ San Martín, 5481 \\ 1407, Caba, Argentina \\ ines.m.califano@gmail.com \\ Received on Nov/5/2012 \\ Accepted on Nov/28/2012
}

\section{INTRODUCTION}

oft tissues comprise over $40 \%-50 \%$ of the total $\mathcal{O}$ body weight; however, hematogenous metastases to these areas are uncommon. It has been hypothesized that muscle and subcutaneous soft tissue are hostile environments for the survival of cancer cells (1).

Although occasionally soft tissue metastases (STM) may present themselves as painful masses, they are usually asymptomatic. Therefore, they may be an unexpected finding in imaging studies (2).
Differentiated thyroid cancer (DTC) is characterized by excellent prognosis and long-term survival. Metastases occur in about $5 \%-10 \%$ of patients. The major sites of metastases are the lungs and bones. Metastatic disease to skeletal muscle is extremely rare and tends to be diagnosed in patients with advanced stage neoplasms (3).

${ }^{18}$-Fluordeoxyglucose positron emission tomography/computed tomography $\left({ }^{18} \mathrm{~F}\right.$ FDG PET-CT) is a useful method for the localization of disease in DTC 
patients with elevated thyroglobulin and negative whole body radioiodine scan, after thyroidectomy and radioiodine ablation. Also, the finding of FDG-avid lesions usually implies in poor prognosis. As ${ }^{18} \mathrm{~F}$ FDG PET-CT yields whole-body imaging, it is not unusual to find foci of metastatic tissue in previously unsuspected sites; this may lead to the modification of treatment strategies in up to $28 \%$ of patients (4).

Two cases of unsuspected STM from DTC that were found by ${ }^{18} \mathrm{~F}$ FDG PET-CT are described in this report.

\section{CASE REPORT 1}

A 26 year-old male without history of exposure to radiation or familial thyroid disease was diagnosed with papillary thyroid cancer (PTC) with peripheral thyroid soft tissues invasion [T3NxM0 EI; risk of recurrence was intermediate according to the ATA guidelines (5) and high according to LATS (6)] in 2002. He was treated elsewhere with total thyroidectomy, lymphadenectomy, and $150 \mathrm{mCi}^{131} \mathrm{I}$. In May 2005, four metastatic left cervical lymph nodes were removed. He received an additional $150 \mathrm{mCi}^{131} \mathrm{I}$ dose, with a negative post-dose scan. Serum thyroglobulin levels during these procedures were not available. Three months later, he was referred to our hospital due to suspicious cervical lymph nodes in the cervical ultrasound. Fine-needle aspiration biopsy (FNAB) confirmed metastatic PTC. The patient underwent a thoroughly surgical revision of the thyroid lodge and lymph node dissection (levels III-IV), which yielded two metastatic lymph nodes out of two resected, the largest measuring $2 \mathrm{~cm}$; the remaining resected material was granulomatous tissue. Subsequently, he had a negative neck ultrasonography. However, six months later, he presented a palpable fixed left cervical mass. FNAB was positive for PTC metastases. Tracheal invasion was suspected on CAT scan, and intraluminal invasion was confirmed by bronchoscopy. In March 2007, asegmental tracheal resection with level VII lymphadenectomy was performed. He received off-label treatment with rosiglitazone as a redifferentiating agent, aiming to restore radioiodine uptake (7) and a new dose of $200 \mathrm{mCi}$ of radioiodine. A post-dose scan showed central neck uptake; stimulated thyroglobulin was $13 \mathrm{ng} / \mathrm{mL}$ with negative antibodies. The patient was lost to follow up until a year later; a mass in the upper mediastinum was observed in MRI; he received another dose of $100 \mathrm{mCi}$ of radioiodine, with a nega- tive post-dose scan, and his stimulated thyroglobulin rose to $96 \mathrm{ng} / \mathrm{mL}$. A ${ }^{18} \mathrm{~F}$ FDG PET-CT (Figure l) showed hypermetabolic foci in the mediastinum and lower neck (SUVm 11,2-14,3), in central nervous system (left frontal lobe, SUVm 10,5, which was confirmed by MRI), and paravertebral dorsal soft tissues (SUVm $6,4)$. FNAB of this lesion was compatible with PTC metastases (Figure 2). Bilateral pulmonary micronodules were observed. Gamma knife surgery of the cerebral metastases was performed, as well as 3D external beam radiotherapy (6000 Cgy) to the neck and mediastinum; both lesions remained stable subsequently. The paravertebral metastases increased its volume. The patient refused surgery and was offered off-label treatment with sunitinib (8).

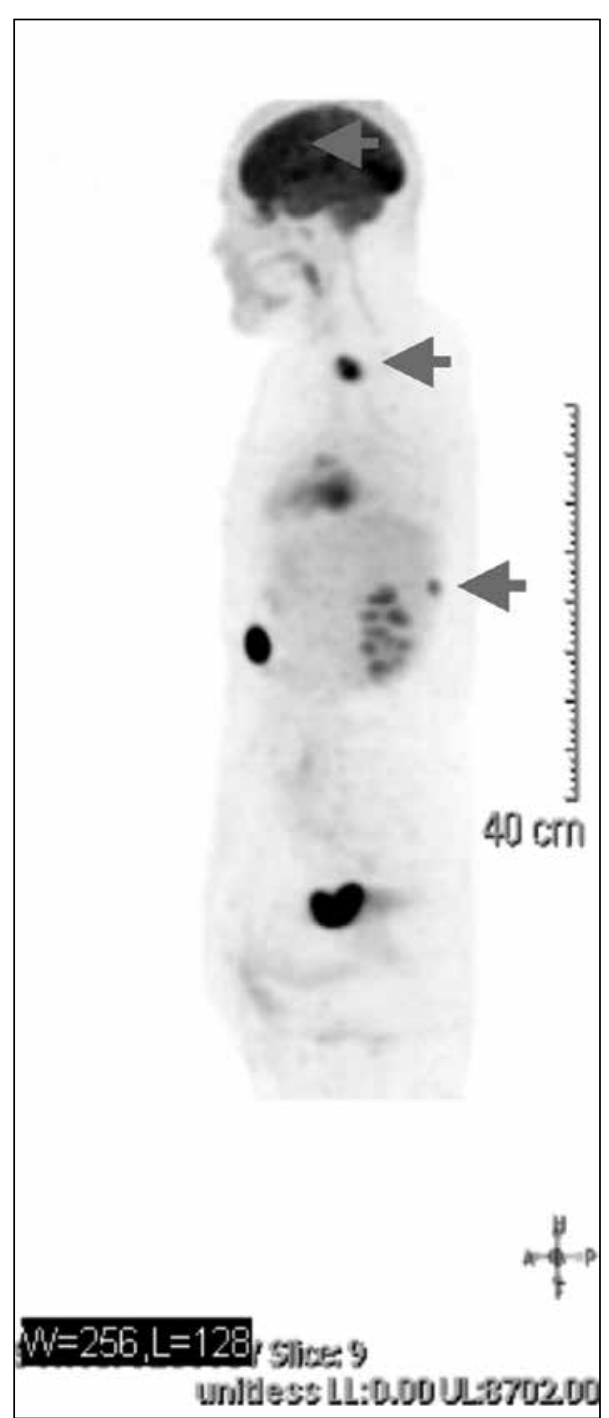

Figure 1. ${ }^{18} \mathrm{~F} \mathrm{FDG} \mathrm{PET-CT} \mathrm{showing} \mathrm{FDG} \mathrm{uptake} \mathrm{in} \mathrm{frontal} \mathrm{lobe} \mathrm{of} \mathrm{the} \mathrm{brain,}$ neck/mediastinum and dorsal soft tissues. 


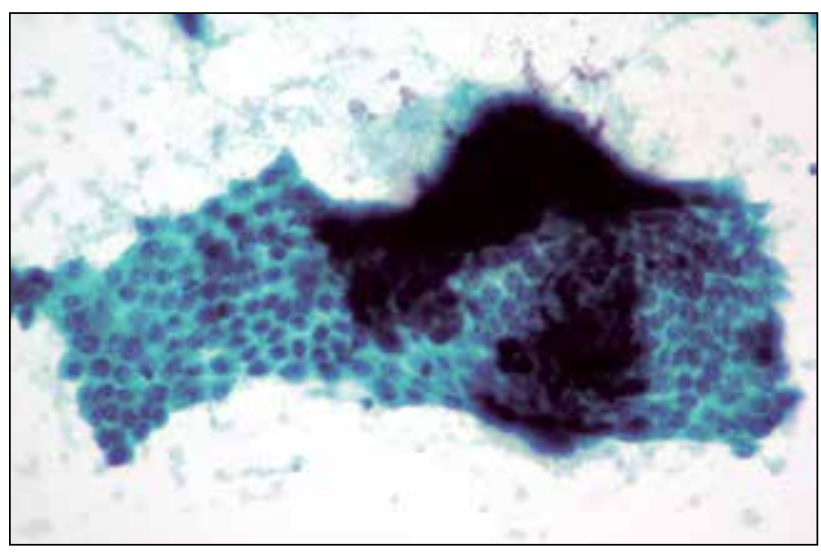

Figure 2. FNAB of dorsal soft tissue lesion showing papillary thyroid cancer metastases.

\section{CASE REPORT 2}

A 64 year-old female with a 30 year history of goiter was diagnosed with follicular variant of papillary thyroid cancer (FVPTC), (T3N0M0 EIII; risk of recurrence was intermediate according to the ATA guidelines, and high according to LATS) in 2003. She was treated elsewhere with total thyroidectomy and ablation with $100 \mathrm{mCi}$ of radioiodine. She was subsequently lost to follow up until 2006, when she was seen because of dyspnea. Extensive invasion of the larynx through the mucosa was observed; total laryngectomy was performed. Histopathological diagnosis confirmed FVPTC. She was then referred to our hospital on 2007. She was given $200 \mathrm{mCi}$ of radioiodine, the post-dose scan showing faint uptake in the neck. Stimulated thyroglobulin was $860 \mathrm{ng} / \mathrm{mL}$, with negative antibodies. Neck sonogram and bone scan were negative for metastases. On the CAT scan, lung micro metastases were observed, as well as a $12-\mathrm{mm}$ image in the pancreas. Levels of CA 19.9 and CEA were normal at that time, sonogram was irrelevant, and close follow-up was decided. A new treatment with $200 \mathrm{mCi}$ of radioiodine was given, with a negative post-dose scan and rising thyroglobulin $(1,390 \mathrm{ng} / \mathrm{mL})$. A ${ }^{18} \mathrm{~F}$ FDG PET-CT scan was performed identifying hypermetabolic foci in the pancreas (a $28 \mathrm{~mm}$ mass with SUVmax 3,9), lower abdominal wall (SUVmax 2,4), and right gluteus $(30 \mathrm{x}$ $25 \mathrm{~mm}$ SUVmax 5,1, Figure 3); stimulated thyroglobulin was $3,259 \mathrm{ng} / \mathrm{mL}$, and antibodies were negative. On the MRI the gluteal lesion was solid and heterogeneous; FNAB showed an adenocarcinoma. A biopsy was performed, confirming PTC metastases (Figure 4). Immunohistological staining revealed positivity for TTFl and thyroglobulin. FNAB of the abdominal wall lesion was positive for fibrosis, and FNAB of the pancreas was unsatisfactory.

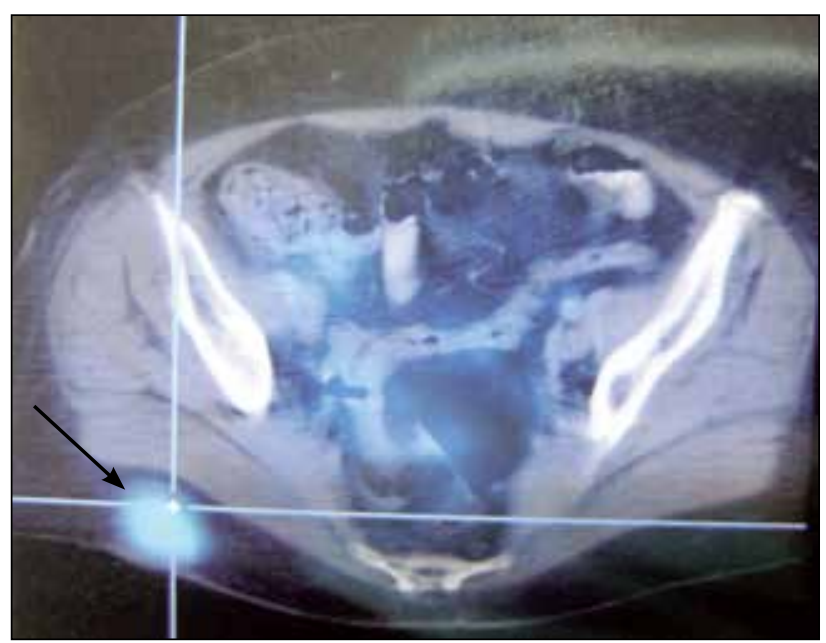

Figure 3. ${ }^{18} \mathrm{~F}$ FDG PET-CT showing a subcutaneous gluteal FDG-avid lesion.

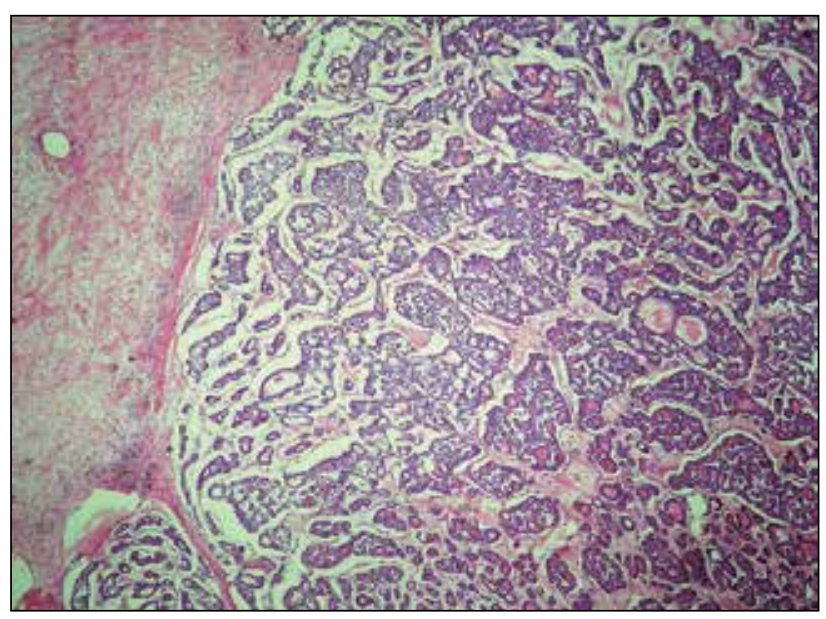

Figure 4. Hematoxilin-eosin showing metastases of papillary thyroid cancer in subcutaneous tissue.

\section{DISCUSSION}

Nearly $10 \%$ of patients with papillary thyroid carcinoma and $20 \%-40 \%$ of follicular subtype die on account of their local disease and distant metastases. Reported rates of occurrence of distant metastases in DTC range from $6 \%$ to $20 \%$ with variation between papillary and follicular subtypes (9). Metastatic disease in DTC has a more favorable course than others malignancies with widespread dissemination, with 10-year survival rates of $50 \%$ in the majority of series. The most frequents sites of distant metastases in DTC are the lungs and bones. Other sites of dissemination are brain, liver, skin, pleu$\mathrm{ra}$, and muscle, but they are less common. Metastases at unusual sites are typical of dedifferentiation, and often arise years after the initial presentation (10). 
Subcutaneous tissue and muscle metastases of DTC are extremely rare events. It is, however, difficult to know the real incidence of this presentation, because reports of cases are scarce $(3,10,11-14)$. According to Song and cols. (15), up to 2011 there were 10 cases of muscle metastases in the English literature.

STM may be an unexpected finding in imaging studies, due to the fact that they are asymptomatic in the majority of the cases. Autopsy series in cancer patients report a prevalence of up to $17 \%$ of skeletal muscle metastases (2); therefore, it is likely that most STM remain undetected clinically and radiographically.

Besides the possibility of underdiagnosis, several factors have been implicated in the rare occurrence of STM, such as muscle motion, mechanical tumor destruction, muscle ability to remove tumor-produced lactic acid, changes in $\mathrm{pH}$, accumulation of metabolites, and local temperature of the soft tissue sites. In addition, blood flow is variable, influenced by adrenergic receptors, and subject to variations in tissue pressure affecting cancer implantation. Whether traumatic injury to soft tissue is a risk factor for STM remains undetermined (1).

The most commonly reported malignancies that result in STM are lung, kidney and colon carcinoma (1); STM from DTC are extremely unusual. They tend to be found in patients with advanced disease, such as the cases we are reporting. Both patients had aggressive disease, showing widespread metastatic dissemination with concomitant loss of radioiodine uptake ability.

The ${ }^{18} \mathrm{~F}$ FDG PET-CT is a sensitive, noninvasive method that allows simultaneous identification and anatomic localization of metastases in patients with elevated thyroglobulin levels and negative radioiodine whole body scans. Additionally, it also provides prognostic information (16). Patients with large tumor volume and elevated SUVm values (as observed in the two cases we report here) are considered to have worse prognosis and shorter survival (17). As ${ }^{18} \mathrm{~F}$ FDG PET-CT yields whole-body imaging, it can identify foci of non-radioiodine avid disease in areas that are not routinely explored. As increasing number of PET-CT scans are performed, it is likely that distant metastases in unusual sites will be more frequently detected. Bae and cols. (18) reported one unsuspected skeletal muscle metastases from papillary thyroid cancer diagnosed by ${ }^{18} \mathrm{~F}$ FDG PET TC. The patient also had recurrent disease in the mediastinum.

STM as the presenting feature of DTC are exceptional (11). In this event, distinction between a met- astatic neoplasm and a primary soft tissue sarcoma is critical because treatment and prognosis are markedly different (1); cytological or histological confirmation of diagnosis is mandatory. In such case, the histological feature of epithelioid neoplasm with tubules and papillary structures is suspicious of synovial sarcoma. In this sarcoma, the immunohistochemical study reveals positivity with CK7, CK19, EMA, BCL2, and CD99, but TTF- 1 and thyroglobulin are negative. The exhaustive study of primary thyroid neoplasm is relevant in the identification of vascular invasion, dedifferentiated areas, extracapsular extension, and evaluation of other component (anaplastic, medullary and tall-cell variant). In both of our patients, extrathyroid extension was noted at diagnosis.

In conclusion, we have reported two cases of skin and muscle metastases of DTC diagnosed by ${ }^{18} \mathrm{~F}$ FDG PET CT. Our report underscores the utility of the method in selected cases to confirm the accurate extension of the disease, and the need for cytological or histological confirmation due to the rarity of the diagnosis.

Disclosure: no potential conflict of interest relevant to this article was reported.

\section{REFERENCES}

1. Plaza J, Perez-Montiel D, Mayerson J, Morrison C, Suster S. Metastases to soft tissue. A review of 118 cases over a 30-year period. Cancer. 2008;112:193-203.

2. Surov A, Hainz M, Holzhausen H, Arnold D, Katzer M, Schmidt J, et al. Skeletal muscle metastases: primary tumors, prevalence and radiological features. Eur Radiol. 2010;20:649-58.

3. Qiu ZL, Luo QY. Erector spinae metastases from differentiated thyroid cancer identified by I-131 SPECT/CT. Clin Nucl Med. 2009;34:137-40.

4. Razfar A, Branstetter B, Christopoulos A, Lebeau S, Hodak S, Heron $D$, et al. Clinical usefulness of positron emission tomography-computed tomography in recurrent thyroid carcinoma. Arch Otolaryngol Head Neck Surg. 2010;136(2):120-5.

5. Cooper D, Doherty G, Haugen B, Kloos R, Lee S, Mandel S, et al. Revised American Thyroid Associaton management guidelines for patients with thyroid nodules and differentiated thyroid cancer. Thyroid. 2009;19(11):1167-214.

6. Pitoia F, Ward L, Wohllk N, Friguglietti C, Tomimori E, Gauna A, et al. Recommendations of the Latin American Thyroid Society on diagnosis and management of differentiated thyroid cancer. Arq Bras Endocrinol Metab. 2009;53(7):884-97.

7. Kebebew E, Peng M, Reiff E, Treseler P, Woeber K, Clark OH, et al. A phase II trial of rosiglitazone in patients with thyroglobulin-positive and radioiodine-negative differentiated thyroid cancer. Surgery. 2006;140:960-6.

8. Carr LL, Mankoff D, Goulart B, Eaton K, Capell P, Kell E, et al. Phase II study of daily sunitinib in FDG-PET-positive, lodine-refractory differentiated thyroid cancer and metastatic medullary 
carcinoma of the thyroid with functional imaging correlation. Clin Cancer Res. 2010;16(21):5260-8.

9. Benbassat C, Mechlis-Frish S, Hirsch D. Clinicopathological characteristics and long-term outcome in patients with distant metastases from differentiated thyroid cancer. World J Surg. 2006;30:1088-95.

10. Bruglia M, Palmonella G, Silvetti F, Rutigliano P, Criante $P$, Marmorale $\mathrm{C}$, et al. Skin and thigh muscle metastasis from papillary thyroid cancer. Singapore Med J. 2009;50 (2):e61-4.

11. Pucci A, Suppo M, Lucchesi G, Celeste A, Viberti L, Pelleritto R, et al. Papillary thyroid cancer presenting as a solitary soft tissue metastasis in an elderly hyperthyroid patient. Case report and review of the literature. Virchows Arch. 2006;48:857-61.

12. Zhao LX, Li L, Li FL, Zhao Z. Rectus abdominis muscle metastasis from papillary thyroid cancer identified by I-131 SPECT/CT. Clin Nucl Med. 2010;35:360-1.

13. Iwai H, Ohno $\mathrm{Y}$, Ito $\mathrm{H}$, Kiyokawa T, Aoki N. Renal rupture associated with a poorly differentiated follicular thyroid carcinoma metastasizing to the thigh muscle, lung and kidney. Intern Med. 2005;44:848-52.

14. Sevinc A, Buyukberber S, Sari R, Baysal T, Mizrak B. Follicular thyroid cancer presenting initially with soft tissue metastasis. Jpn J Clin Oncol. 2000;30(1):27-9.

15. Song HJ, XueYL, XuYH, Qiu ZL, Luo QY. Rare metastases of differentiated thyroid carcinoma: pictorial review. Endocr Relat Cancer. 2011;18:R165-74.

16. Robbins R, Quiang W, Grewal R, Reibke R, Gonen M, Strauss H, et al. Real-time prognosis for metastatic thyroid carcinoma based on 2-[18f] fluoro-2-deoxy-glucose-positron emission tomography scanning. J Clin Endocrinol Metab. 2006;91(2):498-505.

17. Pace $L$, Nicolai $E$, Klain $M$, Salvatore M. Diagnostic value of FDG/ PETTC imaging. O J Nucl Med Mol Imaging. 2009;53:503-12.

18. Bae S, Lee S, Koo M, Hur S, Choi M, Cho D, et al. Distant, solitary skeletal muscle metastasis in recurrent papillary thyroid carcinoma. Thyroid. 2011;21(9):1027-31. 